\title{
Characterization of Siderophore Producing Rhizobacteria and Its Effect on Growth Performance of Different Vegetables
}

\author{
A. Pahari and B.B. Mishra* \\ Department of Microbiology, College of Basic Science and Humanities, Orissa University of \\ Agriculture and Technology, Bhubaneswar - 751 003, Odisha, India \\ *Corresponding author
}

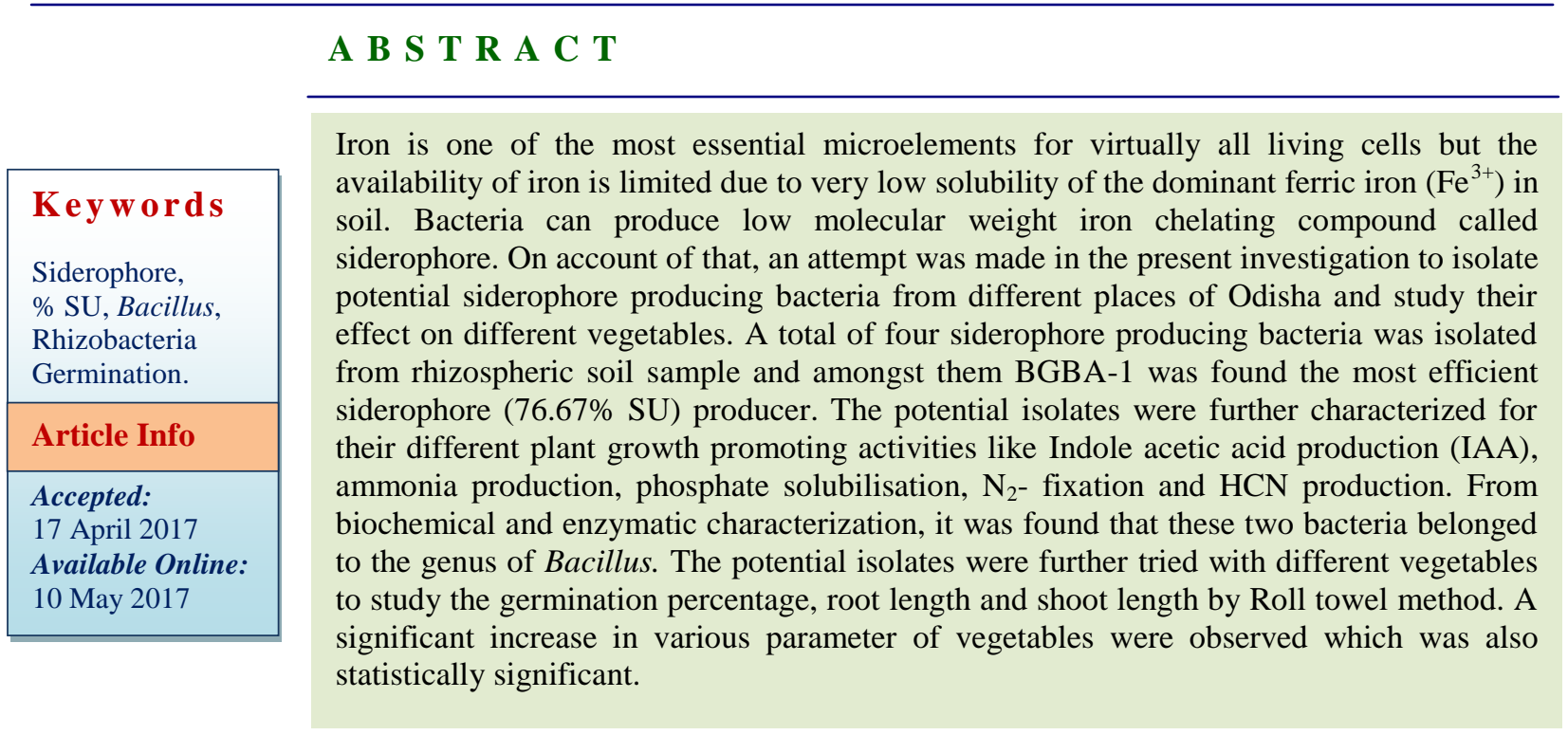

\section{Introduction}

Rhizosphere is a dynamic environment which harbours diverse group of microbes. Some of the bacteria can pivotal role in the plant growth, referred to as plant growth promoting rhizobacteria (PGPR). In the view of increasing demand for food with deteriorating environmental quality due to application of agrochemicals, plant growth promoting rhizobacteria is steadily increasing in agriculture as, it supplement fertilizers and prevent growth of phytopathogens by a wide range of mechanisms. PGPR can promote the plant growth by various direct and indirect mechanism such as phosphate solubilisation, nitrogen fixation, Indole-3-acetic acid (IAA) production, siderophore production and repression of soil borne pathogens by production of hydrogen cyanide \& antibiotics (Glick, 1995).

Iron is one of the most essential microelements for virtually all living cells, is usually abundant in the environment, particularly in soils. Despite being most abundant element in earth's crust, the availability of iron is limited due to very low solubility of the dominant ferric iron $\left(\mathrm{Fe}^{3+}\right)$ in soil and become unavailable to plants as a 
micronutrient (Thompson and Troeh, 1973). Some bacteria have the capability to produce low molecular weight (500-1000 dt) metal chelating compound including iron, called as Siderophore. Siderophore chelate iron from mineral phases by formation of soluble $\mathrm{Fe}^{3+}$ complexes that can be taken up energy dependent membrane transport mechanism and make it available to plants or bacterial cells (Ali et al., 2013).

In nature, different types of siderophore such as hydroxymate, catecholets and carboxylate, are produced by different bacteria. Hydroxymate siderophore possess $\mathrm{N}$ hydrosylated amide bonds as co-ordination sites, catecholates co-ordinate iron with catecholate hydroxyl group and carboxylates co-ordinate iron with carboxyl and hydroxyl groups (Bholay et al., 2012).

Siderophore produced by rhizosphericbacteria improve rhizosphere colonization and play an important role in iron mineralization \&supplement to plant (Vansuyt et al., 2007). Moreover it also play important antagonistic role against phytopathogens (Chincholkar et al., 2007b). In recent years, the role of siderophore-producing PGPR in biocontrol of soil-borne plant pathogens has created a great interest as it prevents growth of pathogens by chelating iron.

On account of that, the present investigation has been undertaken to isolate the potential siderophore producing bacteria from rhizosphere soil of rice from three different locations of Khurda and Ganjam district of Odisha, India and the potential isolates were tried with different vegetables to evaluate the efficacy in increasing germination (\%), root length and shoot length under in viro conditions and quantitative analysis of siderophore production by the isolates was undertaken.

\section{Materials and Methods}

\section{Sample collection and bacterial isolation}

Soil sample was collected from the rhizosphere region of Rice plant from different locations of khurda and Ganjam district of Odisha and intact root system was dug out. The rhizospheric soil sample was carefully collected in plastic bags under aseptic conditions. The soil sample was air dried and subjected to the isolation of bacteria by spread plate technique. A total of 31 bacteria were isolated from the rhizospheric soil sample and they are further characterized for siderophore production.

\section{Screening for siderophore production}

Siderophore productions by all the isolates were tested qualitatively by Chrome Azural S (CAS) plate assay (Schwyn and Neilands, 1986). Freshly grown bacterial isolates were inoculated on CAS agar plates and incubated at $30 \pm 2^{\circ} \mathrm{C}$ for $24-48$ hours. After proper incubation period, siderophore production was confirmed by the presence of orange colour zone around the colony on CAS agar plates and total four positive colonies were isolated.

\section{Quantification of siderophore}

The quantitative estimation of siderophore produced by isolates was done by the CASshuttle assay, in which the isolates were grown in succinate medium (Meyer and Abdallah, 1978) and incubate for 24-48 hr at $30 \pm 2^{\circ} \mathrm{C}$ with constant shaking at $120 \mathrm{rpm}$.

After the incubation supernatant was collected and siderophore present in the aliquot was determined at $630 \mathrm{~nm}$ by using formula: [(ArAs)]/Ar x 100, where Ar is the absorbance at $630 \mathrm{~nm}$ of reference (CAS assay solution + uninoculated media) and As is the absorbance 
at $630 \mathrm{~nm}$ of the sample (CAS assay solution + suparnatnt) (Payne, 1994).

In vitro screening of isolates for different plant growth promoting characters

All rhizobacterial isolates obtained were screened for different plant growth promoting traits. Each culture was placed on modified Pikovskaya agar (Pikovaskya et al., 1948) with insoluble tricalcium phosphate (TCP) and incubated at $30 \pm 0.1^{\circ} \mathrm{C}$ for 5 days to check the phosphate solubilization. IAA production was assayed using qualitative method developed by Bric et al., (1991). Bacterial cultures were inoculated in nutrient broth with tryptophan $(1 \mathrm{mg} / \mathrm{ml})$ incubated at $35 \pm 2^{\circ} \mathrm{C}$ for 7 days. Cultures were centrifuged at $3000 \mathrm{rpm}$ for $30 \mathrm{~min} .2 \mathrm{~mL}$ of supernatant was mixed with 2 drops of orthophosphoric acid and $4 \mathrm{ml}$ of Salkowski's reagent $(50 \mathrm{ml}, \quad 35 \%$ perchloric acid; $1 \mathrm{ml} \quad 0.5 \quad \mathrm{FeCl} 3)$. The development of a pink colour indicated Indole Acetic Acid (IAA) production (Loper and Schroth, 1986). Bacterial isolates were tested for the production of ammonia in peptone water. Freshly grown cultures were inoculated in $10 \mathrm{ml}$ peptone water in each tube and incubated for $48 \mathrm{~h}$ at $35 \pm 2^{\circ} \mathrm{C}$. Nessler's reagent $(0.5 \mathrm{ml})$ was added in each tube. Development of brown to yellow colour observed was a positive test for ammonia production (Cappuccino and Sherman, 1992). Isolates were further screened for $\mathrm{HCN}$ production. Bacterial cultures were streaked on nutrient agar medium containing $4.4 \mathrm{~g} / \mathrm{L}$ of glycine. A Whatman filter paper No. 1 soaked in $0.5 \%$ picric acid solution (in $2 \%$ sodium carbonate) was placed inside the lid of a plate. Plates were sealed with parafilm and incubated at $35 \pm 2^{\circ} \mathrm{C}$ for 4 days (Castric et $a l .$, 1975). For nitrate to nitrite, reduction was detected during the test. Bacteria were inoculated into nitrate broth and incubated incubated at $30 \pm 1^{\circ} \mathrm{C}$ for $96 \mathrm{~h}$. After inoculation, sulphanillic acid and $\alpha$-naphthyl amine mixture (1:1) was added. The appearance of deep pink colour indicated a positive result. N2-fixation ability of the isolates was checked by the using $\mathrm{N}$-free agar based Jensen (1951) agar media and incubated for $72 \mathrm{~h}$ at $30 \pm 1^{\circ} \mathrm{C}$.

\section{Identification, biochemical characterization and enzymatic activities of bacterial isolates}

The potential isolates were further characterized on the basis of their staining characteristics and further investigated in terms of biochemical properties like indole, catalase, urease, citrate, ammonia, nitrate producing abilities and enzymatic activities like amylase, cellulase, gelatinase, caesinase and fermentation of various sugars, which helped in identifying the bacteria up to genus level (Gupta et al., 2000) by Bergey's manual of Determinative bacteriology (Holt et al., 1994) and ABIS online software.

\section{Trial with seed germination}

Bacterial isolates, BGBA-1, BGBA-2, BRBA-1 and BRBA-2 were tried with different vegetables for seed germination under lab condition. Brinjal (Solanum melongena L.), Okra (Abelmoschus esculentus L.) and tomato (Solanum lycopersicum L.) seeds were collected from Dept. of Vegetable science, OUAT and were surface sterilized with $0.1 \% \mathrm{HgCl}_{2}$ for $2 \mathrm{~min}$ and rinsed with sterile distilled water for 10 times. Bacterial isolates were grown in respective broth on shaking incubator (180 rpm) at $28 \pm 2^{\circ} \mathrm{C}$ for $24 \mathrm{~h}$. Cell densities in the suspension were adjusted to a final density of approximately $10^{8} \mathrm{CFU}$ seed $^{-1}$.

The surface sterilized seeds were inoculated in broth culture for $30 \mathrm{~min}$ (ISTA, 1993). Germination tests were carried out using the paper towel method. Treated seeds and 
control were seeded onto paper towels. Germination percentage was measured with the following formula: Germination percentage $=$ Number of germinated seeds / Number of seeds in sample $\times 100$. Root length and shoot length of individual was then measured.

\section{Statistical analysis}

All the experiment was done in triplicate and the data was analyzed statistically by one way ANOVA at $p<0.05$ significant level.

\section{Results and Discussion}

\section{Screening of siderophore positive strain} and Quantitative estimation of siderophore

The siderophore positive isolates were screened by using the colour change of CAS reagent from blur to orange in CAS agar plates. Out of 31 bacterial isolates, four bacterial isolates i.e. BGAB-1, BGAB-2, BRABA-1 and BRBA-2 were positive for siderophore production.

In quantitative estimation of siderophore, percent of siderophore units were estimated in terms of percent decolonization. In the present investigation, it was found that out of four isolates, BGBA-1 and BRBA-1 produced $76.67 \%$ and $74.56 \%$ (Fig. 1) siderophore units after $48 \mathrm{hr}$ of incubation period. It was already proved that the maximum siderophore production by the Bacillus sp. observed after 48 hr (Pahari et al., 2016).

Plant growth promoting activities of the bacterial isolates

A total of four siderophore positive bacterial isolates were further characterized for their different plant growth promoting activities. It was observed that out of four bacterial isolates BGBA-1 and BRBA-1 were positive for IAA production. IAA in the rhizosphere depends on the availability of precursors and uptake of microbial IAA by plant (Arshad and Frankenberger, 1991; Pradhan and Mishra, 2015). On Pikovskaya medium, BGBA-1, BGBA-2 and BRBA-1 showed a development of sharp halo zones (Table 1). Similar observations has been reported by Ngomle et al., 2014, who state that microorganisms capable of producing a clear zone due to $\mathrm{P}$ solubilization in the surrounding medium were selected as potential phosphate solubilizers and where clear zones around the colonies indicated the capacity of phosphate solubilization on Pikovskaya medium. Furthermore, all of the bacterial isolates also exhibited strong production of ammonia from peptone water (Table 1), which is another important trait of PGPR and taken up by plants as a source of nitrogen for their growth (Ahmad et al., 2008). None of the isolates were positive for $\mathrm{HCN}$ production.

Table.1 Plant growth promoting functions of the isolates

\begin{tabular}{|l|c|c|c|c|}
\hline \multicolumn{1}{|c|}{ Test } & BGBA-1 & BGBA-2 & BRBA-1 & BRBA-2 \\
\hline Siderophore production & + & + & + & + \\
\hline HCN production & - & - & - & - \\
\hline $\mathrm{NH}_{3}$ production & + & + & + & + \\
\hline IAA production & + & - & + & - \\
\hline $\mathrm{N}_{2}$ fixation & + & - & + & - \\
\hline Phosphate solubilization & + & + & + & - \\
\hline
\end{tabular}


Table.2 Physiological and biochemical properties of the siderophore producing bacteria

\begin{tabular}{|l|c|c|c|c|}
\hline \multicolumn{1}{|c|}{ TEST } & BGBA 1 & BGBA 2 & BRBA 1 & BRBA 2 \\
\hline Catalase & - & + & - & + \\
\hline $\mathrm{H}_{2}$ S production & - & - & - & - \\
\hline Indole & + & - & + & - \\
\hline Methyl red test & - & - & + & - \\
\hline VP & - & - & - & - \\
\hline Nitrate reduction & + & + & + & + \\
\hline Urease production & + & - & + & + \\
\hline Citrate utilization & - & - & - & - \\
\hline Oxidase & + & + & + & + \\
\hline Mannitol motility & - & - & - & - \\
\hline Aesculin hydrolysis & + & + & + & + \\
\hline Anaerobic growth & + & + & + & + \\
\hline ONPG & + & - & + & + \\
\hline
\end{tabular}

Table.3 Extracellular enzymatic activities of the potential bacterial isolates

\begin{tabular}{|l|c|c|c|c|}
\hline \multicolumn{1}{|c|}{ Test } & BGBA-1 & BGBA-2 & BRBA-1 & BRBA-2 \\
\hline Gelatinase & + & + & + & + \\
\hline Casein hydrolysis & + & + & + & - \\
\hline Tributyrin & + & + & + & - \\
\hline Amylase & + & + & + & + \\
\hline Cellulase & + & - & + & - \\
\hline Chitin hydrolysis & - & - & - & - \\
\hline Pectin hydrolysis & + & + & + & + \\
\hline DNase & - & - & - & - \\
\hline Lecithinase & - & - & - & - \\
\hline
\end{tabular}

Table.4 Identification of bacterial isolates by ABIS online software

\begin{tabular}{|c|c|c|}
\hline Isolate No. & Identification & Matching \% \\
\hline BGBA-1 & Bacillus licheniformis & $76 \%$ \\
\hline BGBA-2 & Bacillus coagulans & $82 \%$ \\
\hline BRBA-1 & Bacillus circulans & $75 \%$ \\
\hline BRBA-2 & Bacillus niacin & $83 \%$ \\
\hline
\end{tabular}


Table.5 Sugar utilization by the siderophore producing bacteria

\begin{tabular}{|c|c|c|c|c|c|c|c|c|c|}
\hline \multirow{2}{*}{$\begin{array}{c}\text { Isolate } \\
\text { No. }\end{array}$} & \multicolumn{3}{|c|}{ Brinjal } & \multicolumn{3}{|c|}{ Okra } & \multicolumn{3}{|c|}{ Tomato } \\
\hline & $\begin{array}{c}\text { Root } \\
\text { length } \\
(\mathrm{cm})\end{array}$ & $\begin{array}{l}\text { Shoot } \\
\text { length } \\
\text { (cm) }\end{array}$ & $\begin{array}{c}\text { Germination } \\
\%\end{array}$ & $\begin{array}{c}\text { Root } \\
\text { length } \\
(\mathrm{cm})\end{array}$ & $\begin{array}{l}\text { Shoot } \\
\text { length } \\
(\mathrm{cm})\end{array}$ & $\begin{array}{c}\text { Germination } \\
\%\end{array}$ & $\begin{array}{c}\text { Root } \\
\text { length } \\
(\mathrm{cm})\end{array}$ & $\begin{array}{l}\text { Shoot } \\
\text { length } \\
\text { (cm) }\end{array}$ & $\begin{array}{c}\text { Germination } \\
\%\end{array}$ \\
\hline Control & $\begin{array}{c}4.19 \\
\pm \\
0.37 \\
\end{array}$ & $\begin{array}{c}6.10 \\
\pm \\
0.30 \\
\end{array}$ & $\begin{array}{c}43.7 \\
\pm \\
1.20 \\
\end{array}$ & $\begin{array}{c}6.55 \\
\pm \\
0.22 \\
\end{array}$ & $\begin{array}{c}8.34 \\
\pm \\
0.20 \\
\end{array}$ & $\begin{array}{c}60.34 \\
\pm \\
0.88 \\
\end{array}$ & $\begin{array}{c}4.76 \\
\pm \\
0.25 \\
\end{array}$ & $\begin{array}{c}8.93 \\
\pm \\
0.22 \\
\end{array}$ & $\begin{array}{c}50.67 \\
\pm \\
2.40 \\
\end{array}$ \\
\hline BGBA 1 & $\begin{array}{c}5.92 \\
\pm \\
0.32 \\
\end{array}$ & $\begin{array}{c}8.73 \\
\pm \\
0.40 \\
\end{array}$ & $\begin{array}{c}69.6 \\
\pm \\
1.45 \\
\end{array}$ & $\begin{array}{c}10.08 \\
\pm \\
0.25\end{array}$ & $\begin{array}{c}12.02 \\
\pm \\
0.35\end{array}$ & $\begin{array}{c}82.00 \\
\pm \\
2.30\end{array}$ & $\begin{array}{c}6.22 \\
\pm \\
0.77 \\
\end{array}$ & $\begin{array}{c}11.06 \\
\pm \\
0.25\end{array}$ & $\begin{array}{c}73.00 \\
\pm \\
3.21 \\
\end{array}$ \\
\hline BGBA 2 & $\begin{array}{c}5.16 \\
\pm \\
0.25\end{array}$ & $\begin{array}{c}8.00 \\
\pm \\
0.41\end{array}$ & $\begin{array}{c}51.0 \\
\pm \\
2.30\end{array}$ & $\begin{array}{c}7.87 \\
\pm \\
0.28\end{array}$ & $\begin{array}{c}10.2 \\
\pm \\
0.29\end{array}$ & $\begin{array}{c}69.00 \\
\pm \\
1.52\end{array}$ & $\begin{array}{c}5.32 \\
\pm \\
0.22 \\
\end{array}$ & $\begin{array}{c}10.17 \\
\pm \\
0.21\end{array}$ & $\begin{array}{c}65.00 \\
\pm \\
1.73\end{array}$ \\
\hline BRBA 1 & $\begin{array}{c}5.35 \\
\pm \\
0.27\end{array}$ & $\begin{array}{c}8.50 \\
\pm \\
0.33\end{array}$ & $\begin{array}{c}62.5 \\
\pm \\
2.18\end{array}$ & $\begin{array}{c}9.93 \\
\pm \\
0.33\end{array}$ & $\begin{array}{c}11.39 \pm \\
0.34\end{array}$ & $\begin{array}{c}77.33 \\
\pm \\
1.20\end{array}$ & $\begin{array}{c}7.22 \\
\pm \\
0.46\end{array}$ & $\begin{array}{c}10.47 \\
\pm \\
0.27\end{array}$ & $\begin{array}{c}71.67 \\
\pm \\
1.86\end{array}$ \\
\hline BRBA 2 & $\begin{array}{c}5.32 \\
\pm \\
0.34 \\
\end{array}$ & $\begin{array}{c}8.17 \\
\pm \\
0.34 \\
\end{array}$ & $\begin{array}{c}61.7 \\
\pm \\
1.44 \\
\end{array}$ & $\begin{array}{c}9.96 \\
\pm \\
0.57 \\
\end{array}$ & $\begin{array}{c}10.13 \pm \\
0.50\end{array}$ & $\begin{array}{c}63.34 \\
\pm \\
1.21 \\
\end{array}$ & $\begin{array}{c}5.03 \\
\pm \\
0.19 \\
\end{array}$ & $\begin{array}{c}9.65 \\
\pm \\
0.24 \\
\end{array}$ & $\begin{array}{c}61.00 \\
\pm \\
1.16 \\
\end{array}$ \\
\hline
\end{tabular}

Values represents mean \pm SE and highly significant at $\mathrm{p}<0.05$

Table.6 Effect of siderophore producing plant growth promoting rhizobacteria on germination percentage, root length and shoot length of different vegetables in germination paper

\begin{tabular}{|c|l|l|l|l|l|l|l|l|l|l|l|l|l|l|l|}
\hline Isolate No. & Tre & De & Du & Sa & Ga & Ino & Me & So & Ma & Su & La & Rh & Mn & Ce & Glu \\
\hline BGBA 1 & - & + & + & + & - & - & + & + & + & - & + & + & - & + & + \\
\hline BGBA 2 & + & + & + & + & - & + & - & + & + & - & + & + & + & + & + \\
\hline BRBA 1 & + & + & + & + & - & + & + & + & + & - & + & + & - & + & + \\
\hline BRBA 2 & + & + & + & + & - & + & + & + & + & - & + & + & - & - & + \\
\hline
\end{tabular}

Tre: Trehalose, De: Dextrose, Du: Dulcitol, Sa:Salicin, Ga: Galactose, Ino: Inositol, Me: Melibiose, So: Sorbitol,

Ma: Maltose, Su: Sucrose, La: Lactos, Rh: Rahmmose, Mn: Mannose, Ce: Cellobiose, Glu:Glucose

Fig.1 Quantification of Siderophore produced by the bacterial isolates

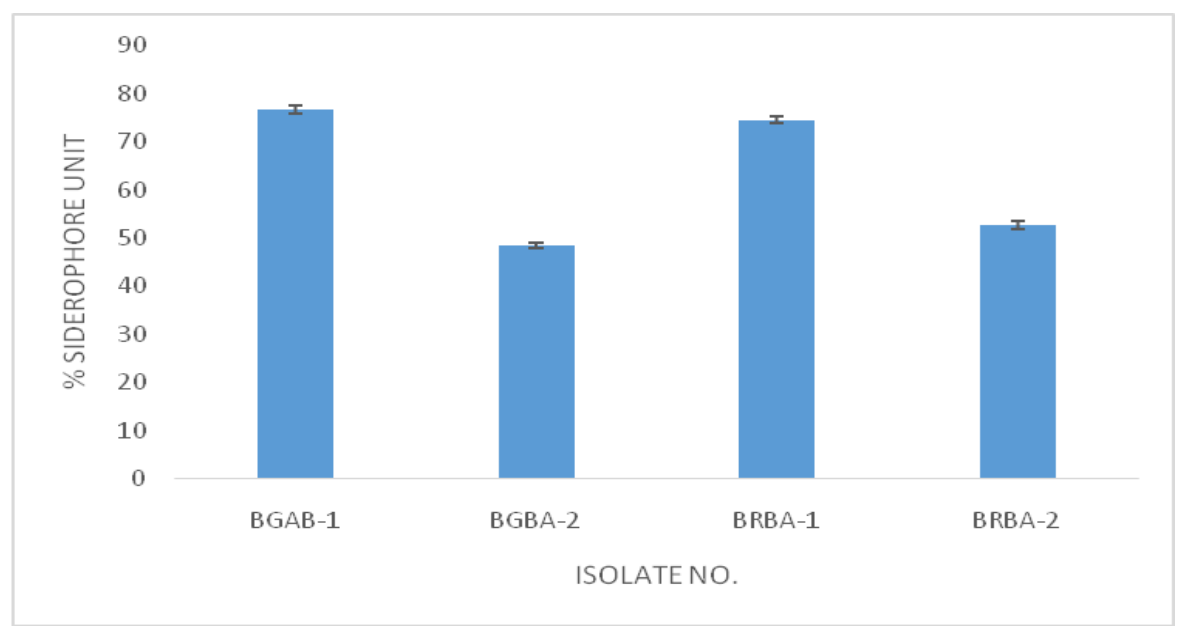




\section{Biochemical characterization and Identification}

The biochemical tests such as oxidase test, nitrate reduction, catalase, carbohydrate utilization, citrate utilization, Indole were carried out for phenotypic identification of isolates (Holt et al., 1994). All of the siderophore producing isolates were positive for maximum biochemical and enzymatic activities (Tables 2 and 3). All of the isolates were positive for maximum sugar utilization (Table 5). The bacterial isolate were characterized by biochemical attributes and were identified as BGBA-1 (Bacillus licheniformis), BGBA-2 (Bacillus coagulans), BRBA-1 (Bacillus circulans) and BRBA-2 (Bacillus niacini) on the basis of ABIS online software (Table 4).

\section{Seed germination test}

In this study, an increase in plant growth by seed bacterization has been demonstrated. Plant growth promoting rhizobacteria increased the synthesis of gibberellins, which would have triggered the activity of specific enzymes including amylase to promote early germination, which have brought an increase in availability of starch assimilation (Bharathi et al., 2004). It is a well-established fact that overall plant growth and root development influenced by improved phosphorous nutrition (Jones et al., 1994). A large number of evidence suggests that PGPR enhance the growth, seed emergence and crop yield (Herman et al., 2008). In the present study, it was found that all of the isolates significantly increased the germination percentage, root and shoot length of brinjal, okra and tomato, over control (Table 6). Highest root (10.08 $\mathrm{cm})$, shoot elongation $(12.02 \mathrm{~cm})$ and germination $(82 \%)$ was recorded when okra seeds were pre-treated with BGBA-1.

The bacteria isolated for the rhizosperic region of rice plant is identified as species of
Bacillus and it is evident from the finding that along with showing positive in many plant growth promoting traits, it is increasing germination, root length and shoot length of different like Brinjal, Tomato and Okra. The increase in the growth parameters is also statistically significant. With further research, the organism can be of great agricultural importance with its application in crop field.

\section{Acknowledgement}

The authors are thankful to Staff of the Department of Vegetable science, OUAT for providing laboratory facilities during the period of study. The authors have no conflict of interest to declare.

\section{References}

Ahmad, F., I. Ahmad and M.S. Khan. 2008. Screening of free-living rhizobacteria for their multiple plant growth promoting activities. Microbiol. Res., 163: 173-181.

Arshad, M. and W.T. Frankenberger. 1991. Microbial production of plant hormones. Plant Soil, 1(133): 1-8.

Ali, S.S. and Vidhale, N.N. 2013. Bacterial Siderophore and their Application: A review. IJCMAS, 2: 303-312.

Bholay, A.D., Jadhav Priyanka, U., Borkhataria, B.V., Mayuri, V., Dhalkari. 2012 Fluorescent Pseudomonads as Plant Growth Promoting Rhizobacteria and Their Siderophoregenesis. IOSR J. Pharmacy and Biol. Sci., (IOSRJPBS), Volume. 3, pp. 27-32.

Bric, J.M., R.M. Bostock and S.E. Silverstone. 1991. Rapid in situ assay for indole acetic acid production by bacteria immobilized on a nitrocellulose membrane. Appl. Environ. Microbiol., 57: 535-538.

Cappuccino, J.C. and N. Sherman. 1992. Microbiology. In: A Laboratory Manual (Eds.: 3rd). New york, Benjamin/cummings Pub. Co., p.125179.

Castric, P.A. 1975. Hydrogen cyanide, a 
secondary metabolite of Psuedomonas aeruginosa. Can. J. Microbiol., 21: 613618.

Chincholkar, S.B., Chaudhari, B.L., Rane, M.R. and Sarode, P.D. 2007b. Fungal phytopathogen suppression using siderophoregenic bio-inoculants. In: Biological Control of Plant Diseases: Current Concepts. Chincholkar, S. B. and Mukerji, K.G. (eds). Haworth Press, USA, pp. 401-417.

Glick, B.R., 1995. The enhancement of plant growth by free-living bacteria. Can. J. Microbiol., 41: 109-117.

Gupta, A., M. Gopal and K.V. Tilak. 2000 Mechanism of plant growth promotion by rhizobacteria. Indian J. Exp. Biol., 38: 856-862.

Herman, M.A.B., Nault, B.A. and Smart, C.D. 2008. Effects of plant growth promoting rhizobacteria on bell pepper production and green peach aphid infestations in New York, 27: 996-1002.

Holt, J., N. Krieg, P. Sneath, J. Staley and S. Williams. 1994. Bergey's manual of determinative bacteriology. Williamson and Wilkins.

ISTA. 1993. Proceedings of the international Seed Testing Association, International Rules for Seed Testing. Seed Sci. Technol., 21: 25-30.

Jensen, H.L. 1951. Notes on the biology of Azotobacter, Proceedings of the Society for Applied Bacteriology.

Jones, D.L., Darrah, P.R. and Kochian, L.V. 1994. Amino acid influx at the soil root interface of Zea mays $\mathrm{L}$. and its implications in the rhizosphere. Plant and
Soil, 163: 1-12.

Loper, J.E. and M.N. Schroth. 1986. Influence of bacterial source of indole-3-acetic acid of root elongation of sugar beet. Phyto Pathol., 76: 386-389.

Ngomle, S., P.M. Bhattacharya., A. Roy and B.S. Ambesh. 2014 Isolation and screening of phosphate solubilizing Bacteria from different crop rhizosphere. The Ecoscan, 6: 505-509.

Pahari, A., Dangar, T.K. and Mishra, B.B. 2016. Siderophore quantification of bacteria from sundarban and its effect on growth of brinjal (Solanum melongena L.). The Bioscan, 11(4): 2147-2151.

Payne, S.M. 1994. Detection, isolation and charectarization of siderophore. Methods of Enzymol., 235: 329-344.

Pikovaskya, R.I. 1948. Mobilization of phosphorus in soil in connection with the vital activity of some microbial species. Mikrobiologiya, 17: 362-370.

Pradhan, A. and B.B. Mishra. 2015. Effect of Plant Growth Promoting Rhizobacteria on germination and Growth of Rice (Oryza Sativa L.).The Ecoscan, 9(1\&2): 213-216.

Schwyn, B. and Neilands, J.B. 1986. Universal Chemical Assay for the detection and determination of siderophores. Anal. Biochem., 140: 47-56.

Thompson, L.M. and F.R. Troeh. 1973. Soils and Soil Fertility, third ed. McGraw-Hill Book Company.

Vansuyt, G., Robin, A., Briat, J.F., Curie, C. and Lemanceau, P. 2007. Iron acquisition from Fe-pyoverdine by Arabidopsis thaliana. Molecular Plant-Microbe Interactions, 2: 441-447.

\section{How to cite this article:}

Pahari, A., and Mishra, B.B. 2017. Characterization of Siderophore producing Rhizobacteria and its Effect on Growth Performance of Different Vegetables. Int.J.Curr.Microbiol.App.Sci. 6(5): 1398-1405. doi: https://doi.org/10.20546/ijcmas.2017.605.152 